\title{
HUBUNGAN KREDIBILITAS KOMUNIKASI PETUGAS PENYULUH KB MELALUI FASE AIDCDA (ATTENTION, INTEREST, DESIRE, CONVICTION, DECISION ACTION DENGAN MINAT BER KB PASANGAN USIA SUBUR (PUS) DI DESA MANUNGGAL TAHUN 2019
}

\author{
${ }^{1}$ Sarida Surya Manurung, ${ }^{2}$ Wulan Sari Ramadhani \\ 1,2 Program Studi S1 keperawatan, Universitas Imelda Medan, Indonesia \\ Email : sarida.manurung1@gmail.com
}

\begin{abstract}
ABSTRAK
Kredibilitas adalah seperangkat persepsi komunikasi tentang sifat-sifat komunikator. Dalam hal ini terkandung dua hal: pertama kredibilitas merupakan persepsi khalayak, jadi tidak melekat dalam diri komunikator, kedua kredibilitas berkenaan dengan sifat-sifat komunikator. Penelitian ini bertujuan untuk menganalisis hubungan kredibilitas komunikasi petugas penyuluh KB terhadap minat ber KB Pasangan Usia Subur (PUS) di Desa Manunggal, menganalisis kredibilitas komunikasi petugas penyuluh KB di Desa Manunggal, menganalisis minat ber KB Pasangan Usia Subur (PUS) di Desa Manunggal. Peneliti menggunakan paradigma positivisme sebagai suatu proses komunikasi linier yang mencerminkan komunikator untuk mengubah pengetahuan (sikap atau perilaku) komunikan yang pasif. Hasil penelitian menunjukkan bahwa hubungan kredibilitas komunikasi petugas penyuluh KB terhadap minat ber KB Pasangan Usia Subur (PUS) di Desa Manunggal memiliki hubungan signifikan. Nilai korelasi Karl Spearman sebesar 0,042 dinyatakan hubungan kedua variabel terdapat hubungan kredibilitas petugas penyuluh KB terhadap minat ber KB Pasangan Usia Subur (PUS) di Desa Manunggal. Kredibilitas komunikasi petugas penyuluh KB Desa Manunggal berdasarkan pada fase AIDCDA (Attention, Interest, Desire, Conviction, Decision, Action) dalam melakukan penyuluhan terhadap minat ber KB Pasangan Usia Subur yang telah dilaksanakan berjalan cukup baik walaupun masih ada kekurangan dalam pelaksanaannya. Dalam hal ini fase yang paling banyak memenuhi kriteria adalah Attention dimana hampir secara keseluruhan responden fokus memperhatikan ke arah komunikator. Sedangkan yang berada di posisi paling sedikit adalah Conviction dimana sebagian responden memilih berbincang kepada rekan sekitar sesama responden mengenai keyakinan untuk memilih jenis KB yang cocok untuk kondisi saat ini. Adapun yang menjadi faktor penghambat yang dialami dalam pelaksanaan sosialisasi yaitu hambatan psikologis, teknis, dan kurangnya komunikator. Minat ber KB Pasangan Usia Subur (PUS) di Desa Manunggal akan dapat ditangani secara baik oleh PLKB dan Pemerintah setempat sesuai dengan perencanaan, pengorganisasian, pelaksanaan, pengawasan dan evaluasi program $K B$.
\end{abstract}

Kata Kunci: Kredibilitas Komunikasi, Fase AIDCDA (Attention, Interest, Desire, Conviction, Decision, Action), Petugas Penyuluh KB, Minat Ber KB Pasangan Usia Subur (PUS).

\begin{abstract}
Credibility is a set of communication perceptions about the traits of a communicator. In this case, there are two things: first, credibility is the perception of the audience, so it is not inherent in the communicator, the second is credibility with regard to the characteristics of the communicator. Manunggal Village, analyzed the communication credibility of KB extension officers in Manunggal Village, analyzed their interest in family planning for fertile age couples (PUS) in Manunggal Village. Researchers use the positivism paradigm as a linear communication process that reflects the communicator to change the knowledge (attitude or behavior) of the passive communicant. The results showed that the relationship between the communication credibility of the family planning extension officers with the interest in family planning for fertile age couples (PUS) in Manunggal Village had a significant relationship. The Karl Spearman correlation value was 0.042, it was stated that the relationship between the two variables was the credibility of the family planning extension officers with the interest in family planning for fertile age couples (PUS) in Manunggal Village. The credibility of the communication of the Manunggal Village Family Planning extension officers is based on the AIDCDA phase (Attention, Interest, Desire, Conviction, Decision, Action) in conducting counseling on the interest in FP for the Fertile Age Couples which has been implemented quite well even though there are still deficiencies in its implementation. The one who met the most criteria was Attention, where almost all respondents focused on paying attention to the communicator. Meanwhile, those who are in the least
\end{abstract}


position are Conviction, where some respondents choose to talk to their colleagues around their fellow respondents about their belief in choosing the type of family planning that is suitable for current conditions. As for the inhibiting factors experienced in the implementation of socialization, namely psychological, technical barriers and lack of communicators. The interest in FP for Fertile Age Couples (PUS) in Manunggal will be handled properly by PLKB and the local government according to planning, organizing, implementing, monitoring and evaluating the family planning program.

Keywords: Communication Credibility, AIDCDA Phase (Attention, Interest, Desire, Conviction, Decision, Action), Family Planning Extension Officers, Interest In Family Planning For Fertile Age Couples (PUS).

\section{PENDAHULUAN}

Keluarga Berencana (KB) merupakan suatu program pemerintah yang dirancang untuk menyeimbangkan antara kebutuhan dan jumlah penduduk. Program keluarga berencana oleh pemerintah adalah agar keluarga sebagai unit terkecil kehidupan bangsa dan diharapkan menerima Norma Keluarga Kecil Bahagia dan Sejahtera (NKKBS) yang berorientasi pada pertumbuhan yang seimbang. Perencanaan jumlah keluarga dengan pembatasan yang bisa dilakukan dengan penggunaan alat-alat kontrasepsi atau penanggulangan kelahiran seperti kondom, spiral, IUD, dan sebagainya (Melani, 2012).

Tingginya pertumbuhan penduduk menjadi salah satu masalah kependudukan baik di Indonesia maupun di negara-negara berkembang yang lain. Salah satu upaya untuk mengatasi tingginya pertumbuhan penduduk ialah dengan melakukan program Keluarga Berencana (KB) untuk mengendalikan fertilitas (Iswandari, dkk., 2016).

Penggunaan kontrasepsi telah meningkat di banyak bagian dunia, terutama di Asia dan Amerika Latin. Secara global, penggunaan kontrasepsi modern telah meningkat dari 54\% pada tahun 1990 menjadi $57 \%$ pada tahun 2012. Secara regional, proporsi wanita usia 15-49 melaporkan penggunaan metode kontrasepsi modern di Afrika sebesar 24\%, Asia sebesar $62 \%$, dan Amerika Latin dan Karibia sebesar 67\% (WHO, 2013).

Berdasarkan data dari profil Kementerian Kesehatan Indonesia tahun 2013 menunjukkan bahwa yang paling banyak digunakan oleh peserta KB aktif adalah suntikan $(46,87 \%)$ dan pil $(24,54 \%)$, sedangkan yang paling sedikit dipilih oleh peserta KB aktif adalah Metode Operasi Pria (MOP) sebesar 0,69\% dan kondom sebesar
$3,22 \%$. Secara nasional, persentase KB aktif tahun 2013 adalah sebesar 76,73\% dan peserta KB baru adalah sebesar 18,49\%. Target RPJMN 2014 untuk cara modern sebesar 60,1\%, namun capaian ber $\mathrm{KB}$ Contraceptive Prevalence Rate (CPR) tahun 2012 baru sebesar 57,9\% (Zuraidah, 2017).

Untuk melandasi pelaksanaan program $\mathrm{KB}$ di Indonesia, pemerintah sudah menetapkan Undang-Undang Nomor 52 Tahun 2009 tentang Perkembangan Kependudukan dan Pembangunan Keluarga. Berdasarkan Undang-Undang tersebut KB mencakup berbagai upaya mengatur kelahiran anak, jarak dan usia ideal melahirkan, mengatur kehamilan melalui promosi, perlindungan dan bantuan sesuai dengan hak-hak reproduksi agar mencapai terwujudnya keluarga yang berkualitas (Dewi, 2016).

Cakupan pelayanan $\mathrm{KB}$ dari BBKBN Provinsi Sumatera Utara di kabupaten/kota, jumlah peserta KB baru adalah sebesar $450.668(20,2 \%)$ terdiri dari IUD $(10,7 \%)$, Metode Operasi Pria (MOP) $(0,7 \%)$, Metode Operasi Wanita (MOW) $(7,7 \%)$, implant $(11,4 \%)$, kondom $(7,4 \%)$, suntik $(32,6 \%)$ dan pil $(29,4 \%)$. Peserta KB aktif adalah 1.577.557 (70,7\%) terdiri dari IUD (6,7\%), Metode Operasi Pria (MOP) $(1,0 \%)$, Metode Operasi Wanita (MOW) (2,5\%), implant $(11,3 \%)$, kondom $(13,5 \%)$, suntik $(33,1 \%)$ dan pil (31,7\%) (Dinkes Pemprovsu, 2015).

Berdasarkan data yang diperoleh dari Badan Pemberdayaan Perempuan dan Keluarga Berencana (BPPKB) Kabupaten Deli Serdang (2014) bahwa jumlah peserta KB sebanyak 380.665 PUS (Pasangan Usia Subur) yang terdiri dari IUD sebanyak 29.292 $(7,7 \%)$, Metode Operasi Wanita (MOW) sebanyak 14.506 (3,8\%), Metode Operasi Pria (MOP) sebanyak $3.390(0,9 \%)$, kondom sebanyak $23.042(6,1 \%)$, implan sebanyak 
$32.383(8,5 \%)$, suntik sebanyak 74.036 $(19,4 \%)$, dan pil sebanyak $77.024(20,2 \%)$ (BPPKB Deli Serdang, 2015).

Pemerintah daerah menyikapi pelaksanaan program $\mathrm{KB}$ tersebut dengan pendekatan komunikasi. Namun beberapa pemerintah daerah tidak memasukkan masalah Kependudukan dan Keluarga Berencana sebagai prioritas utama karena dianggap kurang strategis. Dampaknya adalah adanya penurunan program KB berdasarkan hasil Survei Demografi Kependudukan Indonesia (SDKI) yang dilakukan setiap lima tahun sekali sejak tahun 1991. Total Fertility Rate (TFR) atau ratarata jumlah anak yang dilahirkan wanita selama usia suburnya tidak mengalami perbaikan, Contraceptive Prevalence Rate (CPR) atau tingkat pemakaian kontrasepsi tidak banyak meningkat, justru keinginan mengikuti program KB yang tidak terpenuhi (unmet need) ditemukan meningkat (Dewi, 2016).

Komunikasi penyuluhan yang dilakukan oleh tenaga penyuluh menjadi penting karena harus mempersiapkan pesan-pesan yang mampu menarik keinginan masyarakat untuk ber KB dengan kualifikasi profesional dalam keahlian, sikap bertanggung jawab dan mampu berhadapan dengan masyarakat dari berbagai latar belakang kepercayaan, pendidikan dan bahkan budaya (Safrida, 2018).

Capaian program KB di Kota Medan dari 299.297 Pasangan Usia Subur (PUS), cakupan peserta KB aktif $191.686(60 \%)$, lebih kecil dibandingkan dengan target nasional dengan capaian 70-80\% PUS menjadi akseptor KB aktif. Kondisi ini juga dipengaruhi oleh jumlah tenaga Penyuluh Lapangan Keluarga Berencana (PLKB) yang ada di BKKBN Kota Medan sebanyak 137 orang ditempatkan pada 21 Kecamatan se Kota Medan. Setiap satu kecamatan memiliki 6-7 orang dengan target sasaran kerja melayani 1.350 PUS (Pasangan Usia Subur) dari total 304.558. Kondisi ini berdampak pada pengelolaan program KB yang dapat berakibat penurunan capaian hasil pelaksanaan program dan meningkatnya angka fertilitas total (Safrida, 2018).

Hasil Survei Demografi dan Kesehatan Indonesia (SDKI) tahun 1991 sampai dengan tahun 2007 menunjukkan trend wanita yang melahirkan di rumah sakit pemerintah dan swasta mengalami peningkatan, namun jumlah persalinan yang meningkat ini tidak diimbangi dengan peningkatan pelayanan $\mathrm{KB}$ pascasalin. Rata-rata ibu yang ber-KB setelah bersalin dan keguguran hanya $5-10 \%$ (BKKBN, 2014).

Menurut penelitian yang berhubungan dengan KB menyatakan bahwa adanya pengaruh penerapan metode CRM (Costemer Relationship Management) terhadap PUS (Pasangan Usia Subur) khususnya aseptor KB untuk meningkatkan kepatuhan berkunjung sesuai jadwal dengan nilai $\mathrm{P}=0,000 \pm \leq 0,05$ di RSU (IPI) Medan tahun 2019. Berdasarkan hasil penelitian diharapkan kepada petugas kesehatan dan peneliti dapat memahami dan meningkatkan pemberian KIE pada ibu (Manurung \& Rizky, 2020).

Jumlah petugas penyuluh KB dalam meningkatkan program KB di Kota Medan menjadi perhatian semua pihak terutama upaya-upaya peningkatan akseptor KB Kota Medan di tahun 2016 dengan pencapaian jumlah PUS sebanyak 363.349 menjadi akseptor KB sebanyak 277.494 atau sama dengan capaian 76,37\% (BKB Kota Medan, 2016).

\section{METODE PENELITIAN}

Penelitian ini merupakan penelitian kuantitatif dengan menggunakan desain deskriptif kolerasi dengan pendekatan pengamatan sewaktu (cross sectional). Penelitian ini dilakukan di Desa Manunggal Kecamatan Labuhan Deli Kabupaten Deli Serdang Tahun 2019. Populasi yang digunakan dalam penelitian ini adalah petugas penyuluh KB yang ada di Desa Manunggal. Sampel dalam penelitian ini Petugas Lapangan Keluarga Berencana yang berada ditiap Dusun dengan teknik pengambilan sampel adalah Non probability Sampling dengan metode accidental sampling. Pengolahan data melalui proses editing, coding, Sorting, Entry data, Cleaning dan mengeluarkan Informasi.

\section{HASIL DAN PEMBAHASAN}

Data hasil penelitian mengenai "Hubungan kredibilitas komunikasi Petugas Penyuluh KB melalui fase AIDCDA (Attention, Interest, Desire, Conviction, Decision, Action) dengan minat ber $\mathrm{KB}$ 
Pasangan Usia Subur (PUS) di Desa Manunggal". Berdasarkan hasil penelitian, karakteristik responden Pasangan Usia Subur (PUS) yaitu kredibilitas komunikasi Petugas Penyuluh KB dan minat ber KB Pasangan Usia Subur (PUS) dapat dilihat dalam tabel dibawah ini.

Tabel 1. Distribusi Frekuensi Responden Berdasarkan Umur, Pendidikan, Pekerjaan Dan Jumlah Anak

\begin{tabular}{cccc}
\hline No & Umur (Tahun) & $\mathbf{F}$ & $\mathbf{( \% )}$ \\
\hline 1 & $20-30$ & 16 & 53,3 \\
\hline 2 & $31-40$ & 14 & 46,7 \\
\hline & Total & 30 & 100 \\
\hline No & Pendidikan & $\mathbf{F}$ & $\mathbf{( \% )}$ \\
\hline 1 & SD & - & 0 \\
\hline 2 & SMP & 3 & 10,0 \\
\hline 3 & SMA & 22 & 73,3 \\
\hline 4 & D-III & 3 & 10,0 \\
\hline 5 & Sarjana & 2 & 6,7 \\
\hline & Total & 30 & 100 \\
\hline No & Pekerjaan & $\mathbf{F}$ & $\mathbf{( \% )}$ \\
\hline 1 & IRT & 23 & 76,7 \\
\hline 2 & Pegawai Swasta & 5 & 16,7 \\
\hline 3 & PNS & - & 0 \\
\hline 4 & Wirausaha & 2 & 6,7 \\
\hline 5 & Lainnya & - & 0 \\
\hline & Total & 30 & 100 \\
\hline No & Jumlah Anak & $\mathbf{F}$ & $\mathbf{( \% )}$ \\
\hline 1 & 1 & 4 & 13,3 \\
\hline 2 & 2 & 20 & 66,7 \\
\hline 3 & $>3$ & 6 & 20,0 \\
\hline & Total & 30 & 100 \\
\hline
\end{tabular}

Berdasarkan tabel diatas, diketahui bahwa mayoritas responden berumur $20-30$ tahun yaitu sebanyak 16 orang $(53,3 \%)$, sedangkan minoritas berumur 31-40 tahun yaitu sebanyak 14 orang (46,7\%). Berdasarkan tingkat pendidikan, mayoritas responden berpendidikan SMA yaitu sebanyak 22 orang $(73,3 \%)$, minoritas berpendidikan Sarjana yaitu sebanyak 2orang $(6,7 \%)$. Berdasarkan pekerjaan, mayoritas responden berprofesi sebagai IRT yaitu sebanyak 23 orang $(76,7 \%)$, minoritas respondenberprofesi sebagai Wirausaha yaitu sebanyak 2 orang $(6,7 \%)$. Berdasarkan jumlah anak mayoritas responden memiliki anak berjumlah 2 yaitu sebanyak 20 orang $(66,7 \%)$, minoritas responden memiliki anak berjumlah 1 yaitu sebanyak 4 orang $(13,3 \%)$.

Tabel 2. Distribusi Frekuensi Responden Berdasarkan Kredibilitas Komunikasi Petugas Penyuluh KB

\begin{tabular}{cccc}
\hline No & $\begin{array}{l}\text { Kredibilitas Komunikasi } \\
\text { Petugas Penyuluh KB }\end{array}$ & F & $\mathbf{( \% )}$ \\
\hline 1 & Baik & 24 & 80,0 \\
\hline 2 & Buruk & 6 & 20,0 \\
\hline & Total & 30 & 100 \\
\hline
\end{tabular}

Berdasarkan tabel diatas, diketahui bahwa mayoritas responden mendapatkan kredibilitas komunikasi Petugas Penyuluh KB sebanyak 24 orang $(80,0 \%)$ yaitu bernilai baik, dan minoritas bernilai buruk yaitu 6 orang $(20,0 \%)$.

Tabel 3. Distribusi Frekuensi Responden Berdasarkan Minat ber KB Pasangan Usia Subur (PUS)

\begin{tabular}{cccc}
\hline No & $\begin{array}{l}\text { Minat ber KB Pasangan } \\
\text { Usia Subur (PUS) }\end{array}$ & F & $\mathbf{( \% )}$ \\
\hline 1 & Baik & 29 & 96,7 \\
\hline 2 & Buruk & 1 & 3,3 \\
\hline & Total & 30 & 100 \\
\hline
\end{tabular}

Berdasarkan tabel diatas, diketahui bahwa mayoritas minat ber KB Pasangan Usia Subur adalah baik yaitu 29 orang $(96,7 \%)$ dan minoritas minat ber KB Pasangan Usia Subur adalah buruk yaitu 1 orang $(3,3 \%)$.

\section{Analisis Bivariat}

Tabel 4. Distribusi Frekuensi Responden Berdasarkan Hubungan Kredibilitas Komunikasi Petugas Penyuluh KB Melalui Fase AIDCDA (Attention, Interest, Desire, Conviction, Decision, Action) Dengan Minat Ber KB Pasangan Usia Subur (PUS) Di Desa Manunggal

\begin{tabular}{|c|c|c|c|c|c|c|c|}
\hline \multirow{2}{*}{$\begin{array}{l}\text { Kredibilitas } \\
\text { Komunikasi PLKB }\end{array}$} & \multicolumn{4}{|c|}{ Minat ber KB Pasangan Usia Subur (PUS) } & \multirow{2}{*}{$\begin{array}{c}\text { Jumlah } \\
\mathrm{N}\end{array}$} & \multirow{2}{*}{$\begin{array}{c}\text { Persentasi } \\
\%\end{array}$} & \multirow{2}{*}{$\frac{\text { p hitung }}{0,042}$} \\
\hline & Baik & $\%$ & Buruk & $\%$ & & & \\
\hline Baik & 24 & 80,0 & 0 & 0 & 24 & 80 & \\
\hline Buruk & 5 & 16,7 & 1 & 3,3 & 6 & 20 & \\
\hline Total & 29 & 96,7 & 1 & 3,3 & 30 & 100 & \\
\hline
\end{tabular}

Berdasarkan tabel diatas, diketahui bahwa dari 30 responden yang diambil di
Desa Manunggal ada 29 responden $(96,7 \%)$ yang memiliki minat ber $\mathrm{KB}$ dan ada 1 
responden $(3,3 \%)$ yang tidak berminat ber KB. Uji Chi-Square diperoleh nilai p hitung $=0,042$ maka $\mathrm{P}$ hitung $<\mathrm{P}$ value $(0,05)$ maka dikatakan (Ha) diterima dan (H0) ditolak, artinya kedua variabel secara statistik mempunyai hubungan yang signifikan.

\subsection{PEMBAHASAN}

Berdasarkan hasil penelitian, diketahui bahwa mayoritas responden berumur 20-30 tahun yaitu sebanyak 16 orang $(53,3 \%)$, sedangkan minoritas berumur 31-40 tahun yaitu sebanyak 14 orang $(46,7 \%)$. Berdasarkan tingkat pendidikan, mayoritas responden berpendidikan SMA yaitu sebanyak 22 orang $(73,3 \%)$, minoritas berpendidikan Sarjana yaitu sebanyak 2orang $(6,7 \%)$. Berdasarkan pekerjaan, mayoritas responden berprofesi sebagai IRT yaitu sebanyak 23 orang $(76,7 \%)$, minoritas responden berprofesi sebagai Wirausaha yaitu sebanyak 2 orang $(6,7 \%)$. Berdasarkan jumlah anak mayoritas responden memiliki anak 2 tahun yaitu/sebanyak 20 orang $(66,7 \%)$, minoritas responden memiliki anak 1 tahun yaitu sebanyak 4 orang $(13,3 \%)$.

Kredibilitas Komunikasi Petugas Penyuluh KB terhadap minat ber KB Pasangan Usia Subur (PUS) di Desa Manunggal berdistribusi normal. Hubungan $\mathrm{X} 1$ dan $\mathrm{Y}$ diperoleh dari 30 responden yang diambil di Desa Manunggal ada 29 responden $(96,7 \%)$ yang memiliki minat ber KB dan ada 1 responden $(3,3 \%)$ yang tidak berminat ber KB. Uji Chi-Square diperoleh nilai p hitung $=0,042$ maka $\mathrm{P}$ hitung $<\mathrm{P}$ value $(0,05)$ maka dikatakan (Ha) diterima dan (H0) ditolak, artinya kedua variabel secara statistik mempunyai hubungan yang signifikan. Artinya, semakin baik komunikasi Petugas Penyuluh KB yang dilakukan tenaga penyuluh lapangan di Kota Medan maka akan semakin meningkat minat ber KB Pasangan Usia Subur di Desa Manunggal atau dapat dikatakan bahwa pengaruh kredibilitas Petugas Penyuluh KB baik untuk peningkatan minat ber KB di Desa Manunggal.

\section{KESIMPULAN}

Dari hasil penelitian terhadap 30 orang responden Pasangan Usia Subur (PUS) berdasarkan hasil analisis data bivariat dan disimpulkan bahwa:
1. Berdasarkan Kredibilitas Komunikasi Petugas Penyuluh KB melalui fase AIDCDA (Attention, Interest, Desire, Conviction, Decision, Action) mayoritas memiliki nilai baik sebanyak 24 orang $(80,0 \%)$ dan minoritas dengan nilai buruk yaitu 6 orang $(20,0 \%)$.

2. Berdasarkan minat ber KB Pasangan Usia Subur (PUS) yaitu 29 orang $(96,7 \%)$ dan minoritas minat ber $\mathrm{KB}$ yaitu 1 orang $(3,3 \%)$.

3. Berdasarkan Hubungan Kredibilitas Komunikasi Petugas Penyuluh KB melalui fase AIDCDA (Attention, Interest, Desire, Conviction, Decision, Action) dengan minat ber KB Pasangan Usia Subur (PUS) Di Desa Manunggal diketahui bahwa dari 30 responden yang bernilai baik untuk ber KB melalui Kredibilitas komunikasi Petugas Penyuluh $\mathrm{KB}$ ada 24 responden $(80,0 \%)$ dan yang bernilai buruk untuk ber $\mathrm{KB}$ melalui Kredibilitas komunikasi PLKB ada 6 responden (20,0\%). Uji Chi-Square diperoleh nilai $\mathrm{p}$ hitung $=0,042$ maka $\mathrm{P}$ hitung $<\mathrm{P}$ value $(0,05)$ maka dikatakan (Ha) diterima dan (Ho) ditolak, artinya kedua variabel secara statistik mempunyai hubungan yang signifikan.

\section{REFERENCES}

Arikunto. 2010. Prosedur Penelitian Suatu Pendekatan Praktek. Edisi Revisi V. Jakarta: Rineka Cipta.

Azwar S. 2011. Sikap Manusia: Teori dan Pengukurannya. Pustaka, Jakarta.

BKKBN. 2014. Kebijakan Pengendalian Penduduk, Keluarga Berencana, dan Pembangunan Keluarga. http// di www.bkkbn.go.id, diperoleh 18 Maret 2019).

BPPKB. 2015. Pendataan Keluarga BPPKB Deli Serdang tahun 2015.

Dewi, D. M. 2016. "Banyak Anak Banyak Rejeki" vs "Dua Anak Cukup" via Program KB di Kota Batam. Journal of Law and Policy Transformation, 1(1), pp. 94-122.

Dinkes Provinsi Sumatera Utara. Profil Kesehatan Sumatera Utara Tahun 2015. Sumut: Dinkes Provinsi Sumatera Utara.

Handayani, S. (2010). Buku Ajaran Pelayanan Keluarga Berencana. Yogyakarta: Pustaka Rihanna. 
Hurlock, Elizabeth B. 2004. Psikologi Perkembangan. Alih bahasa: Ishwidayati. Edisi V. Jakarta: Erlangga.

Ikbal, Muhammad. 2011. Pengaruh Motivasi Terhadap Minat Mahasiswa Akuntansi untuk Mengikuti Pendidikan Ppak: Studi Kasus Pada Mahasiswa Akuntansi Universitas Diponegoro Semarang.

Indriyatmo. 2015. Hubungan Antara Dukungan Keluarga Dengan Motivasi Untuk Sebuah Pada Pasien Kanker Yang Menjalani Kemoterapi Di ruang One Day Care RSUD Dr. Moewardi. Diakses pada tanggal 23 Maret 2019 pukul: 21:10

Irianto. 2014. Pelayanan Keluarga Berencana. Edisi ke 1. Bandung: Balai Penerbitan Alfabeta.

Iswandari, N.D., Handayani, L. \& Asi, R., 2016. Analisis Perilaku Akseptor Keluarga Berencana Terhadap Metode Kontrasepsi Jangka Panjang di Puskesmas Tewah. Dinamika Kesehatan. 7(2), pp.193-209.

Maksimus. 2014. Komunikasi Terapeutik. Jakarta: Graha ilmu.

Manurung, S. S., \& Rizky, M. (2020). Pengaruh Penerapan Metode CRM (Costemer Relationship Management) Terhadap PUS (Pasangan Usia Subur) Dan Aseptor KB Khususnya Jenis Kb Berkunjung Sesuai Jadwal Di Rumah Sakit Umum Imelda Pekerja Indonesia (RSU IPI) Medan Tahun 2019. Jurnal Ilmiah Keperawatan IMELDA, 6(1), 18. http://jurnal.uimedan.ac.id/index.php/JU RNALKEPERAWATAN/article/view/3 76.

Melani, N. (2012). Pelayanan Keluarga Berencana: dilengkapi dengan penuntut belajar. Yogyakarta: Fitramaya.

Nazir, Moh. 2014. Metodologi penelitian. Jakarta: Ghalia Indonesia.

Notoatmodjo, S. 2010. Metodologi Penelitian Kesehatan. Jakarta: Rineka Cipta.

Notoatmodjo, S. 2012. Promosi kesehatan, teori dan aplikasi. Cetakan II. Jakarta: Rineka cipta.

Nurudin. 2016. Ilmu Komunikasi Ilmiah dan Populer. Jakarta: Raja Grafindo Persada.

Rakhmad, Jalaludin. 2012. Psikologi Komunikasi. Bandung: Remaja Rosda Karya.
Safrida, Viana. 2018. Pengaruh Kredibilitas Komunikasi Penyuluh Lapangan Keluarga Berencana (PLKB) Terhadap Peningkatan Akseptor Keluarga Berencana Di Kota Medan. Jurnal Interaksi. Vol 2 No. 2, Juli 2018, 145 156.

Siti. 2015. Komunikasi dan Konseling dalam pelayanan kebidanan. Yogyakarta: Fitramaya.

Sugiyono, 2011. Metode penelitian kombinasi (Mixed Methods). Bandung : Alfabeta .

Susilowati, Eva Teguh. 2010. Hubungan Minat Menonton Tayangan Film Kartun Laga Di Televisi Pada Agresivitas Siswa SDN Ngimbang Palang Tuban. Diakses pada tanggal 27 Maret 2019 pukul: 20:17.

WHO. 2013. Data Penggunaan Kontrasepsi Dunia. Jakarta: WHO.

Zuraidah. 2017. Pengaruh Pengetahuan terhadap Persepsi Istri dalam penggunaan KB Non Hormonal. Midewife journal. Volume 3 No.1 Januari 2017. 